\title{
A revision of Hicksbeachia (Proteaceae)
}

\author{
Peter H. Weston
}

\begin{abstract}
Weston, Peter H. (National Herbarium of New South Wales, Royal Botanic Gardens, Sydney, Australia 2000) 1988. A revision of Hicksbeachia (Proteaceae). Telopea 3(2): 231-239, figs 1-2. - The genus Hicksbeachia is revised and descriptions given of seedling and adult characters of both species. Hicksbeachia pilosa is described and its geographic variability discussed.
\end{abstract}

\section{Introduction}

Hicksbeachia has generally been regarded as a monotypic genus consisting of $H$. pinnatifolia $\mathrm{F}$. Muell., a widespread species disjunctly distributed from the Nambucca River in north-eastern New South Wales to Tambourine Mountain in south-eastern Queensland and from the Cardwell Range to the Big Tableland in north-eastern Queensland (see e.g. Francis 1929, Floyd 1978). Although Sleumer (1955) transferred Helicia diversifolia C. White to Hicksbeachia, Johnson and Briggs (1975) subsequently described a new genus, Athertonia, to accommodate this species. Johnson and Briggs (1975) also suggested that the northern Queensland populations of Hicksbeachia sens. strict. constitute a different species from those in south-eastern Australia. In the course of preparing a treatment of Hicksbeachia sens. strict. for the 'Flora of Australia', I have confirmed that the northern Queensland populations are morphologically different from those in south-eastern Australia. Indeed, there may be more than one taxon in northern Queensland. At present, however, the northern Queensland populations are not known well enough to support any further distinction of taxa there.

Since the two taxa of Hicksbeachia are markedly allopatric, either specific or subspecific rank could be considered appropriate for them. However, according to the evolutionary species concept that I have adopted (Wiley 1978, 1981), morphologically different allopatric lineages should be given specific rank. Therefore I am describing a new species, $H$. pilosa, encompassing, for now, all of the north Queensland Hicksbeachia populations.

Hicksbeachia has not been critically studied since Maiden (1917) and since then herbarium collections of the genus have increased considerably. Moreover, study of seedlings has revealed additional characters for the discrimination of the genus and the species.

The nearest relative of Hicksbeachia is likely to be the subtribe Gevuininae or any genus, or a combination of genera, in the subtribe Hicksbeachiinae, or all of the above-mentioned taxa (Johnson \& Briggs 1975). The Gevuininae and Hicksbeachiinae appear to form a clade characterised by the synapomorphous chromosome number of $n=13$, reduced from $n=14$, which is ancestral for the Macadamieae (Johnson \& Briggs 1975).

Hicksbeachia is characterised by several likely synapomorphies. The cotyledons become prominently pilose after germination commences, a character that is otherwise unknown in the Macadamieae (unpublished observations). 
Turrillia lutea has minutely pubescent cotyledons but this condition is unlikely, on morphological grounds, to be homologous with the pilose cotyledons of Hicksbeachia. The pronounced cauliflory of Hicksbeachia is likely to be a synapomorphy for the genus though several closely related genera such as Virotia, Athertonia and Gevuina exhibit ramiflory to some extent. The pattern of dissection of intermediate leaves in Hicksbeachia (see below) is different to that in all other genera of Macadamieae though the leaves of Gevuina bleasdalei and $G$. papuana approach it. The cladistic generality of this feature is unclear at present: the pinnatifid intermediate leaves of Athertonia, for example, could be a further derivation of it.

While a few specimens of $H$. pilosa have truly pinnate leaves (Fig. 1a), the majority of specimens of both species have what I have termed pinnatepinnatifid leaves (Fig. 1b). In this latter condition the leaf is pinnate at the base and the pinnae there are shortly petiolulate. The leaf rachis may or may not be winged between the two most basal pairs of pinnae. More distally, the pinnae are replaced by pinnatisect lobes in which the serial homologue of each pinna is fused with the rachis wing immediately below it. The leaf tip is deeply pinnatifid, that is each pinna homologue is fused to the homologues of both adjacent rachis wings. The rachis wings and their homologues are much more strongly developed in $H$. pinnatifolia than in $H$. pilosa.

Several authors and collectors (e.g. Maiden 1917; Floyd 1978, letter in NSW; Lander specimen 324; B. Hyland pers. comm.) have reported or noted flowers of both species to emit a pungent odour, resembling honey, sour milk, mice or cat's urine, particularly around dusk. This prompted Floyd (letter in NSW) to speculate that the (unknown) pollination vectors might be moths. Johnson and Briggs (1975) suggest that some rainforest Grevilleoid genera with pendulous conflorescences, including Hicksbeachia, may be pollinated by fruit bats. Hicksbeachia, however, does not obviously fit any of the pollination syndromes described by Faegri \& van der Pijl (1966).

Strohschen (1986) provides a detailed account of fruit and seed development in $H$. pinnatifolia. She classifies the fruit as a transitional stage between a follicle and nut.

Hicksbeachia F. Muell. (1883: 33) 20-21).

Maiden (1917: 235-239); Johnson \& Briggs (1975: 134-135); Floyd (1978:

TYPE SPECIES: Hicksbeachia pinnatifolia F. Muell.

Small rainforest trees to $15 \mathrm{~m}$, usually with one or a few unbranched stems arising from ground level; leaves restricted to near the tips of the stems. Seedling leaves simple, serrate to laciniate, acuminate, shortly petiolate with a prominent rounded base, with semicraspedodromous venation (Hickey 1973); first pair of seedling leaves opposite, ovate to elliptical; following seedling leaves alternate, progressively more narrow-obovate and with an increasing length/ width ratio; intermediate leaves serrate to laciniate, pinnatifid to pinnatepinnatifid, oblanceolate in general outline. Adult leaves alternate, pinnate to pinnate-pinnatifid with a winged rachis, serrate, narrow-obovate in general outline; pinnae oblong to narrow-oblong or sometimes ovate to narrow-ovate, acuminate, with strongly oblique bases, occasionally the most basal pinnae being trilobed to trifoliolate; venation of wings, lobes and pinnae 


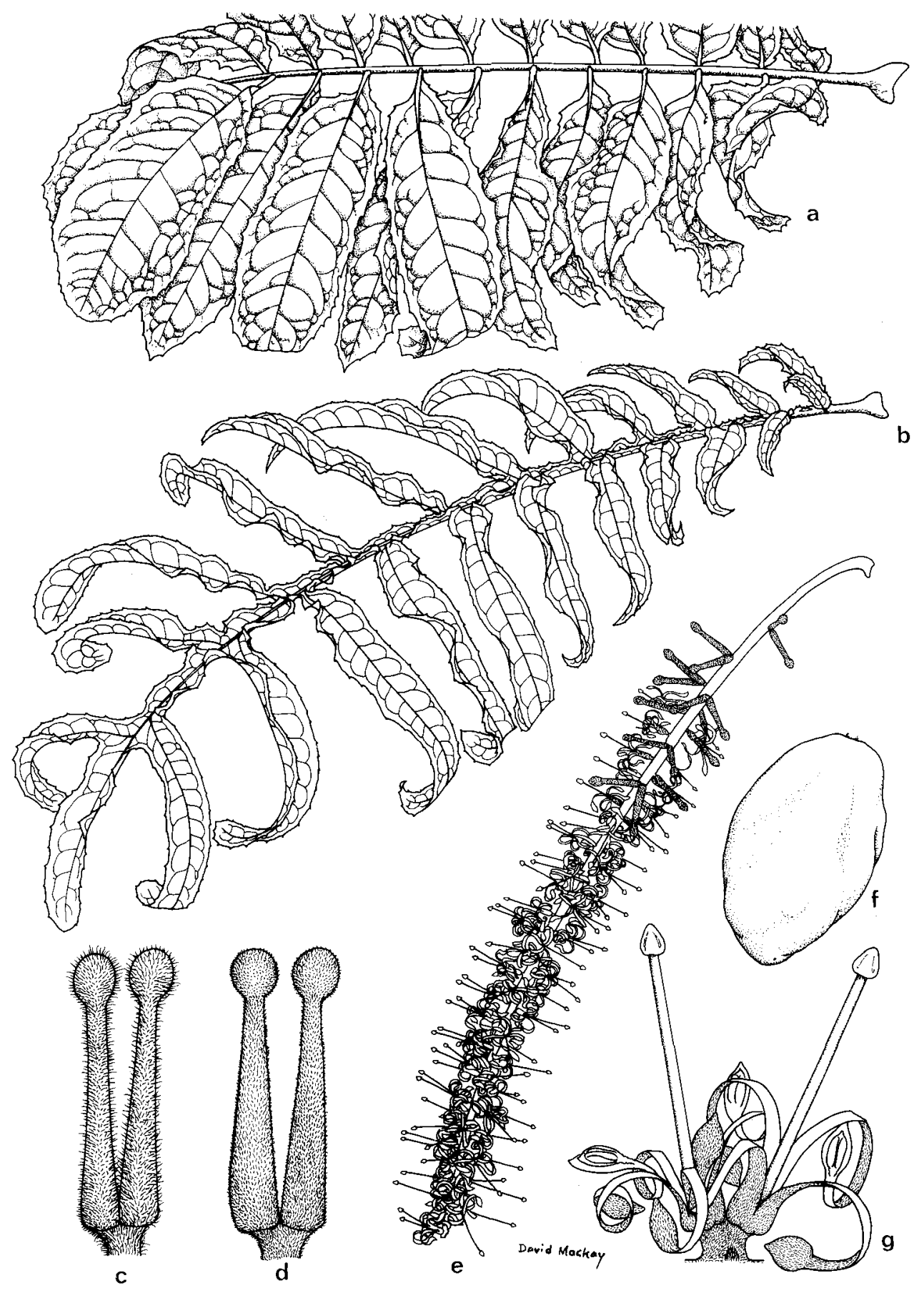

Fig. 1. a, adult leaf of $H$. pilosa (x 1/4). b, adult leaf of $H$. pinnatifolia (x 1/4). c, uniflorescence of flower buds of $H$. pilosa (x 3). d, uniflorescence of flower buds of $H$. pinnatifolia (x 3). e, conflorescence of $H$. pinnatifolia $(\mathrm{x} 1 / 2)$. f, fruit of $H$. pinnatifolia (x 1). g, uniflorescence of flowers of $H$. pinnatifolia (x 3). (Drawn from Hyland 6767 (a), Thorne, Jones \& Tracey NSW 130729 (b), du Rietz 4340 (c), and fresh material cultivated at the Royal Botanic Gardens, Sydney - voucher Coveny 10187 (d-g).) 
semicraspedodromous; leaf bases prominent, rounded. Conflorescences axillary, cauliflorous, pendulous, unbranched; flower pairs borne on short but distinct uniflorescence axes, bracteate. Flowers ebracteate, sessile to pedicellate, hermaphrodite, actinomorphic; floral orientation antero-posterior. Tepals not coherent, revolute. Staminal filaments almost completely adnate to the tepals; anthers free, oblong, apiculate. Hypogynous glands 4, free, fleshy, truncate, square in dorsal view, \pm triangular in cross-section. Ovary sessile. Style filiform, terminated by the ovoid pollen-presenter. Stigma terminal. Fruit ellipsoid to ovoid, indehiscent, with a prominent ventral suture at maturity, dehiscing along the ventral suture and dorsally on germination; outer mesocarp succulent, traversed by radially oriented fibres; inner mesocarp bony, consisting of closely packed, tangentially oriented, fibre-capped vascular bundles and lignified parenchyma. Seed solitary, wingless, fleshy; testa thin and papery. Embryo ellipsoidal, lacking endosperm; cotyledons 2 or rarely 3 , hemi-ellipsoidal, white and glabrous before germination, green spotted with purple, shortly auriculate, hypogeal to scarcely epigeal, pilose after germination. $n=13$ (Johnson \& Briggs 1975: 169).

A genus of at least 2 species, endemic to eastern Australia. The embryo is an edible 'nut'.

\section{Key to the species}

1 Conflorescences and young shoots pubescent; leaves coriaceous; leaf rachis prominently winged throughout.

1. H. pinnatifolia

$1^{*}$ Conflorescences and young shoots pilose; leaves chartaceous; leaf rachis prominently winged only towards the tip.

2. H. pilosa

1. Hicksbeachia pinnatifolia $F$. Muell. (1883: 33); Bailey (1901: 1333-1334); Maiden (1917: 235-239); Floyd (1978: 20-21).

TyPe: New South WAlES: near the Tweed, C. Fawcett s.n.; not found. The only material of Hicksbeachia pinnatifolia held by MEL, annotated by Mueller, precisely dated and agreeing with the protologue was collected by Fawcett a month or two after the publication of this name. No type material has been located elsewhere. There is, however, no doubt as to the correct application of this name. The type locality and Mueller's description of the leaves ('leaflets decurrent along the rachis'; 'of rigid texture'), conflorescence axes ('somewhat silky') and tepals ('outside slightly silky') are consistent only with the species from south-eastern Australia.

Illustrations: M. Flockton in Maiden (1917: pl. 222); E.R. Rotherham in Rotherham et al. (1975: figs. 330-331).

First internode and pair of seedling leaves moderately pilose when immature, glabrescent with age; later developed seedling leaves and internodes progressively more ferruginous-pubescent when immature. Adult branchlets moderately to densely ferruginous-pubescent when young, glabrescent with age. Adult leaves coriaceous, $34-90 \mathrm{~cm}$ long, pinnate-pinnatifid with 10-35 lobes and pinnae; rachis prominently winged throughout; pinnae 2-24; pinnatisect lobes $0-13$; pinnatifid lobes $2-9$; lobes and pinnae usually prominently recurved towards the tips, otherwise flat to concave, with flat to scarcely recurved and often sinuate margins, usually not bullate; largest pinnae $14-40 \mathrm{~cm}$ long, $2.5-5.5(-7) \mathrm{cm}$ wide; secondary and tertiary veins prominently raised on both 
surfaces. Conflorescence axes $14-50 \mathrm{~cm}$ long, densely ferruginous-pubescent; flower pair bracts $0.3-1 \mathrm{~mm}$ long; uniflorescence axes $0.3-3 \mathrm{~mm}$ long. Pedicels 0-1.5 mm long. Tepals $15-20 \mathrm{~mm}$ long, moderately ferruginous-pubescent, maroon outside, cream to pink inside. Gynoecium 14-19 mm long, maroon; ovary densely hairy. Fruit pinkish red to scarlet, $30-50 \mathrm{~mm}$ long, $20-28 \mathrm{~mm}$ wide. Fig. 1.

VARIATION: variation within regional populations seems to be about the same as that between them.

FlOWERING PERIOD: sporadically throughout the year but mainly from August to October.

NOTE: $H$. pinnatifolia often regenerates prolifically after felling by suckering from the base; it may be lignotuberous.

DisTRIBUTION: Occurs from Tambourine Mountain, south-eastern Queensland, to the Nambucca Valley of north-eastern New South Wales; in, and on the margins of, subtropical rainforest, from near sea level to 700 metres altitude. Fig. 2.

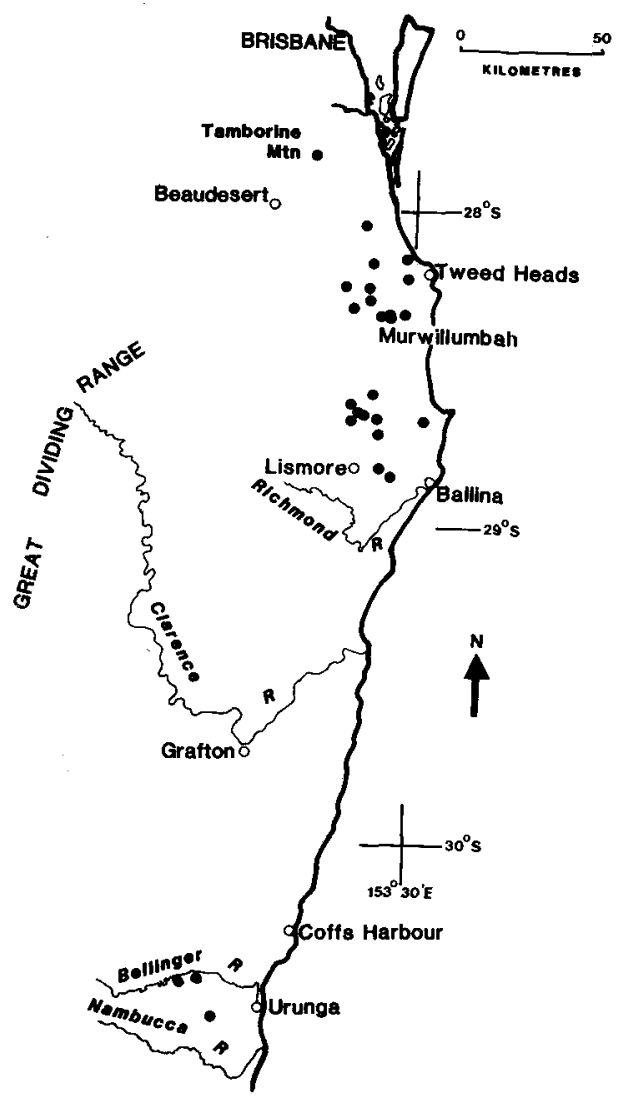

Fig. 2. Distribution of $H$. pinnatifolia. 
Number of Collections Examined: 37.

Selected Specimens: New South Wales: North Coast: Tweed River, Fawcett s.n. 3.1883 (MEL 109015); $17.6 \mathrm{~km}$ NNE of Lismore, $0.8 \mathrm{~km}$ past the Rocky Creek turnoff, $28^{\circ} 39^{\prime} \mathrm{S} 153^{\circ} 21^{\prime} \mathrm{E}$, Coveny 4440 \& Rodd, 3.9 .1972 (BRI, NSW, QRS); Duroby Creek, on Bilambil-North Tumbulgum road, at falls, $28^{\circ} 15^{\prime} \mathrm{S} 153^{\circ} 27^{\prime} \mathrm{E}$, Lander 324, 30.8.1973 (BRI, NSW); Kennaicle Ck road, $4.6 \mathrm{~km}$ from Missabotti, 30 32'S $152^{\circ} 49^{\prime} \mathrm{E}$, Weston 1077, Hill \& Johnson, 17.10.1987 (AK, BRI, CBG, K, MEL, MO, NSW, QRS).

QueEnSLAND: Moreton: upper Currumbin Creek, White 6409, 6.11.1929 (BRI).

\section{Hicksbeachia pilosa $P$. Weston, sp. nov.}

Differt a $H$. pinnatifolia surculis immaturis ferrugineopilosis, foliis chartaceis plerumque bullatis, rhachidi folii prominenter alata tantum versus apicem, conflorescentiis ferrugineopilosis, tepalis malvinis ad purpuratis.

Holotype: QueEnsland: Cook: Bobbin Bobbin Falls, $17^{\circ} 22^{\prime} \mathrm{S} 145^{\circ} 46^{\prime} \mathrm{E}$, P.H. Weston 959, G. Sankowsky \& P. Hind, 23.8.1986 (NSW - 5 sheets). IsOTYPES: BRI, QRS.

Seedling internodes and leaves moderately pilose when immature, glabrescent with age; seedling leaves 7-15. Adult branchlets moderately to densely ferruginous-pilose when young, glabrescent with age. Adult leaves moderately ferruginous-pilose when immature, glabrescent or retaining hairs only on the rachis and around the main veins when mature, chartaceous, (35-)54-90 cm long, pinnate to pinnate-pinnatifid with 7-32 lobes and pinnae; rachis prominently winged only towards the tip; pinnae 3-28; pinnatisect lobes $0-14$; pinnatifid lobes $0-5$; lobes and pinnae not recurved to moderately recurved towards the tips, convex with moderately to prominently recurved but scarcely sinuate margins, usually prominently bullate between the secondary and tertiary veins; largest pinnae (11-)18-34 cm long, $(2.5-) 4.5-8.5(-10) \mathrm{cm}$ wide; secondary and tertiary veins prominently raised on the abaxial surface, usually only slightly raised on the adaxial surface. Conflorescence axes $15-30(-56) \mathrm{cm}$ long, densely ferruginous-pilose; flower pair bracts $0.3-1 \mathrm{~mm}$ long; uniflorescence axes $0.3-3 \mathrm{~mm}$ long. Pedicels $0-1.5 \mathrm{~mm}$ long. Tepals $19-23 \mathrm{~mm}$ long, moderately ferruginous-pilose, mauve to deep purple. Gynoecium 18-23 mm long, mauve to deep purple with an orange pollen-presenter; ovary densely hairy. Fruit orange to scarlet, 40-47 mm long, 26-30 mm wide. Fig. 1.

The specific epithet refers to the pilose indumentum of the young shoots and conflorescences.

VARIATION: $H$. pilosa is much more variable over its range than $H$. pinnatifolia, though this could reflect the presence of more than one species within my current concept of $H$. pilosa. The only group of populations that $I$ have seen in the field are on the western side of Mt Bartle Frere and nearby at Boonjee Logging Area. The flowers in these populations are mauve, the fruits scarlet and the conflorescences $15-30 \mathrm{~cm}$ long. Other regional variants are characterised below.

(i) Big Tableland-Cedar Bay (Hyland 6784, Dick s.n.). These specimens have smaller, less bullate leaves than most other specimens. Flowers are stated to be 'purple'. Fruits have not been collected but Dick noted them to be 'brownish yellow and corrugated'.

(ii) Noah Creek (Hyland 7034). This specimen has smaller, slightly coarser, less bullate leaves than most other specimens. Flowers and fruits are unknown. 
(iii) Stewart Creek (Smith 4040, Sankowsky 566). Conflorescences are much longer $(35-56 \mathrm{~cm})$ than in other specimens $(15-30 \mathrm{~cm})$. G. Sankowsky (pers. comm.) confirms the large conflorescences in this population and notes also that the leaves are very large, the flowers are deep purple with an orange pollenpresenter and the fruits are orange.

(iv) Mossman-Julatten (Gray 1458, Carr 2). Flowers are of a similar colour to those of the Stewart Creek population but conflorescences are an average size. Fruits are unknown.

The only specimen from the eastern side of the Bellenden Ker Range (Flecker s.n., 29.8.1949) apparently resembles most closely those from the Mossman-Julatten area. Its flowers are noted as having a 'purple and orange colour'. Fruits from this population are unknown. Herbarium specimens from the Tully-Cardwell Range area are indistinguishable from those from the western side of Mt Bartle Frere but flower colour and fruits are unknown.

FLOWERING PERIOD: June to November.

DISTRIBUTION: Occurs from The Big Tableland to the Cardwell Range, northeastern Queensland; in rainforest, from near sea level to 400 metres altitude.

Fig. 3.

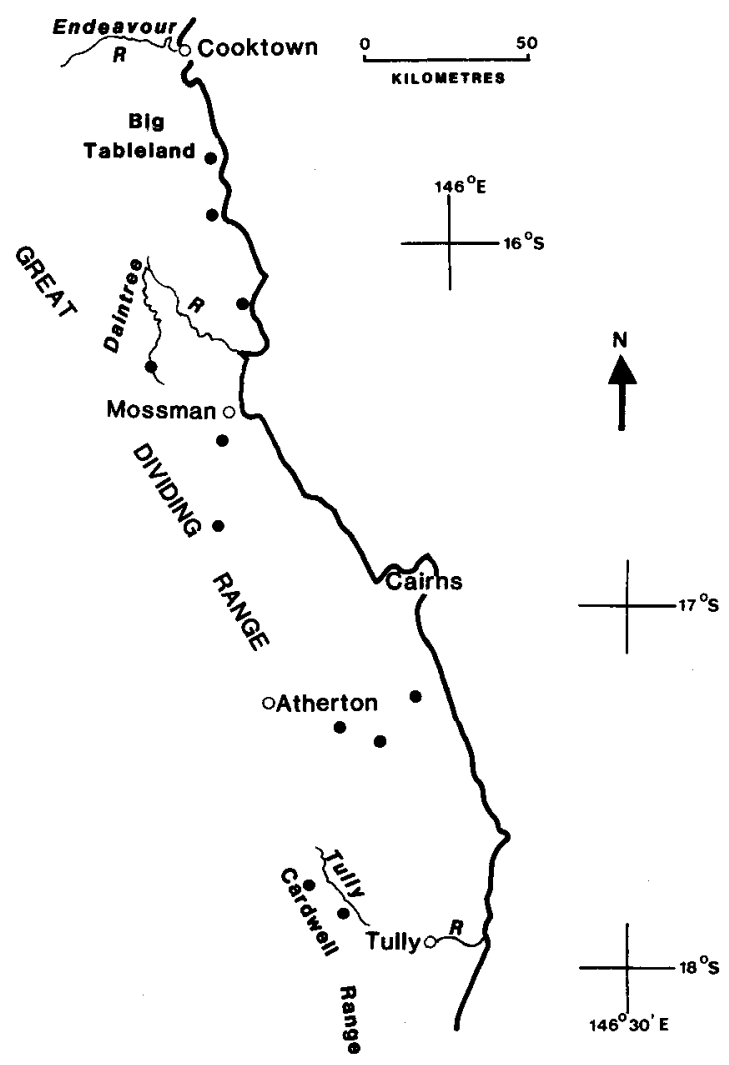

Fig. 3. Distribution of $H$. pilosa. 
SPECIMENS EXAMINED: QueEnSland: Cook: Timber Reserve 146 Home Rule Logging Area, $15^{\circ} 45^{\prime} \mathrm{S} 145^{\circ} 20^{\prime} \mathrm{E}$, Hyland 6784, 26.7.1973 (QRS); Cedar Bay, Dick s.n., 12.1969 (BRI); V.C.L. Noah (near Noah Creek), $16^{\circ} 10^{\prime} \mathrm{S} 145^{\circ} 25^{\prime} \mathrm{E}$, Hyland 7034, 7.11.1973 (QRS); Stewart Creek, Smith 4040, 8.9.1948 (BRI); Stewart Creek, $16^{\circ} 18.6^{\prime}$ S 145 $18.7^{\prime}$ E, Sankowsky 566, 11.1986 (NSW); State Forest Reserve 143, Little Mossman Logging Area, 16 $32^{\prime} \mathrm{S} 145^{\circ} 22^{\prime} \mathrm{E}$, Gray 1458, 6.6.1979 (QRS); Julatten, Rumula, Carr 2, 4.1932 (BRI); Harveys Creek, Flecker s.n., 29.8.1949 (BRI); cultivated, Atherton from seed collected from State Forest Reserve 310, Windin Logging Area, Hyland 6767, 20.7.1973 (NSW, QRS), Hyland 9762, 27.9.1978 (NSW, QRS); Bobbin Bobbin Falls, 17 $22^{\prime} \mathrm{S}$ $145^{\circ} 46^{\prime} \mathrm{E}$, Weston 959a, Sankowsky \& Hind, 23.8.1986 (BRI, NSW); Mt Bartle Frere above Bobbin Bobbin Falls, du Rietz 4340, 8.1927 (BRI); Mt Kooroomool, Cardwell Range, Flecker s.n., 12.11.1949 (QRS); Tulty Falls, Fielding s.n., 8.1949 (NSW).

\section{Excluded species}

Hicksbeachia diversifolia (C. White) Sleumer (1955: 6).

BASIONYM: Helicia diversifolia C. White (1918: 18).

HOLOTYPE: 'Atherton district, H.W. Mocatta' (BRI).

= Athertonia diversifolia (C. White) L. Johnson \& B. Briggs (1975: 176).

\section{Acknowledgements}

I am grateful to the directors of BRI, MEL and QRS for the loan of their specimens of Hicksbeachia. Bernie Hyland, Nan Nicholson and Garry Sankowsky supplied their own field observations of Hicksbeachia and seeds or seedlings for study. These plants were maintained in cultivation by Penny Kater and the staff of the nursery, Royal Botanic Gardens, Sydney. David Mackay drew Fig. 1 for the 'Flora of Australia' under contract to the Bureau of Flora and Fauna. Louisa Murray drafted the maps. I am grateful to Jim Armstrong and Lawrie Johnson for useful discussions and to Karen Wilson and Bernie Hyland for critically reading an earlier draft of the manuscript. Gordon Guymer kindly searched for type material of Hicksbeachia pinnatifolia at $\mathrm{K}$ and BM in his capacity as Australian Botanical Liaison Officer.

\section{References}

Bailey, F.M. (1901) 'The Queensland Flora'. Part 4 (Diddams \& Co.: Brisbane).

Faegri, K., \& van der Pijl, L. (1966) 'The Principles of Pollination Ecology' (Pergamon Press: London).

Floyd, A.G. (1978) N.S.W. rainforest trees, part VII. Forestry Commission N.S.W. Research Note 35.

Francis, W.D. (1929) 'Australian Rain-Forest Trees' (Commonw. Govt Printer: Brisbane).

Hickey, L.J. (1973) Classification of the architecture of dicotyledonous leaves. Amer. J. Bot. 60: 17-33.

Johnson, L.A.S., \& Briggs, B.G. (1975) On the Proteaceae - the evolution and classification of a southern family. Bot. J. Linn. Soc. 70: 83-182.

Maiden, J.H. (1917) 'Forest Flora of New South Wales'. Vol. 6 (Govt Printer: Sydney).

Mueller, F. (1883) Definitions of some new Australian plants. S. Sci. Rec. 3: 33-34.

Rotherham, E.R., Briggs, B.G., Blaxell, D.F., \& Carolin, R.C. (1975) 'Flowers and Plants of New South Wales and Southern Queensland' (A.H. \& A.W. Reed: Sydney).

Sleumer, H. (1955) Studies in Old World Proteaceae. Blumea 8: 2-95.

Smith, A.C. (1985) 'Flora Vitiensis Nova: a New Flora of Fiji' (Pacific Tropical Botanical Garden: Lawai). 
Strohschen, B. (1986) Contributions to the biology of useful plants 5. Anatomical studies of fruit development and fruit classification of the Monkey Nut (Hicksbeachia pinnatifolia F. Muell.). Angew. Botanik 60: 249-256.

White, C.T. (1918) Contributions to the Queensland flora. Queensland Dept Agric. Bull. 20: $5-20$.

Wiley, E.O. (1978) The evolutionary species concept reconsidered. Syst. Zool. 27: 17-26.

Wiley, E.O. (1981). 'Phylogenetics: The Theory and Practice of Phylogenetic Systematics' (Wiley: New York).

Manuscript received 12 March 1987

Manuscript accepted 6 July 1987 